CONFERENCE PAPER

\title{
ALTERNATIVE METHODS FOR VASOPUNCTURING IN VETERINARY MEDICINE: ARTIFICIAL RABBIT EAR
}

\author{
Merim Tabaković ${ }^{1}$, Aida Omanović ${ }^{2 *}$
}

${ }^{1}$ Department of Anatomy and Histology with Embryology, Veterinary Faculty, University of Sarajevo, Bosnia and Herzegovina, Zmaja od Bosne 90, 71000 Sarajevo

2*Student of Veterinary Faculty, University of Sarajevo, Bosnia and Herzegovina, Zmaja od Bosne 90, 71000 Sarajevo

*Corresponding author:

Aida Omanović, student

Veterinary Faculty, University of

Sarajevo

Sarajevo, Bosnia and Herzegovina

Address: Zmaja od Bosne 90, 71000

Phone: +38762607079

E-mail:

aida_omanovic123@outlook.com

\begin{abstract}
Veterinary students often learn to perform basic procedures on live animals obtained from laboratories or shelters. In the era of modern technologies, there is a constant endeavour for live animals to be replaced by alternative, artificial models. Practicing on different anatomical models contributes to better quality of students' future approach to animals in practice. For purposes of this study, many experiments with various materials were made until solution to cheaper, but efficient method of alternative learning, was found. We created the artificial rabbit ear with the purposes of practicing and mastering vasopuncturing technique from both marginal ear vein and central ear artery. Made out of silicone materials, it gives elasticity and softness closest to the ear auricle, and blood vessels are replaced by inner tubes filled with artificial color. The model represents anatomically correct features of European brown hare's ear (Lepus europaeus) with dual purpose, since the accent is put on correct and, of course, humane learning.
\end{abstract}

Keywords: anatomical models, rabbit ear, silicone models, vasopuncture

\section{INTRODUCTION}

Humane innovations in veterinary education gained big importance in the past decade. Many studies on this subject have showed that tests and experiments on animals for educational purposes were inhumane and unnecessary considering so many alternatives available. For many years, simulation has been used in education to help students improve 
their practical learning skills and performance, but also to prevent errors. There is also a risk of a patient suffering related to the lack of proficiency in students' practical skills (Havnes et al., 2017). A lot of techniques were developed to prepare and preserve anatomical specimens for studying veterinary anatomy (Arnautović et al., 2005; Avdić et al., 2006; Avdić et al., 2014). In the last decade, 3D models and VR technologies alike are growing ever more popular throughout industries all over the world, and are becoming especially common in the medical education, especially anatomy (Cod and Choudhury, 2011; Seo et al., 2021). Regarding animal welfare, nowadays trends are to create artificial models for learning purposes made up of available materials, such as clay, wax, polymer, plaster, etc. However, those available in the market are usually costly, lowdurable or once damaged, cannot be repaired. We came up with the idea to make an artificial ear for practicing blood collecting technique, also known as vasopuncture in order to avoid physical and psychological trauma in laboratory rabbits (and other animals used for learning). This study was

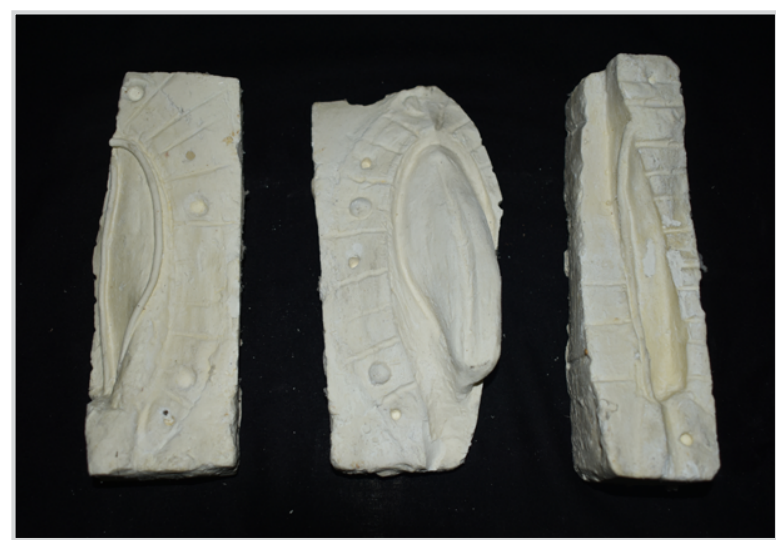

Figure 1.

Plaster ear mold. Models can be produced only several times due to brittleness and difficulty in fixating all parts together. focused on making silicone models that are of low cost, durable, and most importantly, functional.

\section{MATERIALS AND METHODS}

The animal used in this study was an adult European brown hare (Lepus europaeus) that was found road-killed. The cadaver was used in making two parts of the model, the ears and body. The first mode of making an ear mold was using plaster (Komar, BiH) because silicone definitely dries in it (Figure 1). But, no matter how hard plaster was reinforced, it was brittle and hard to fix all parts together. In quest to make something easier to use, and more durable, we approached with another mode, which resulted in much better results. We made a mold using fiberglass and general-purpose polyester resin (Dugapol H 230 P, Duga, Serbia) mixed with the catalyst and hardener provided. Since drying process required presence of air, the mold had to be made from three parts connected with screws (Figure 2). In one part of the mold (medial side of the ear), a thin layer of acetate silicone (Tekasil, TKK, Slovenia) was applied and

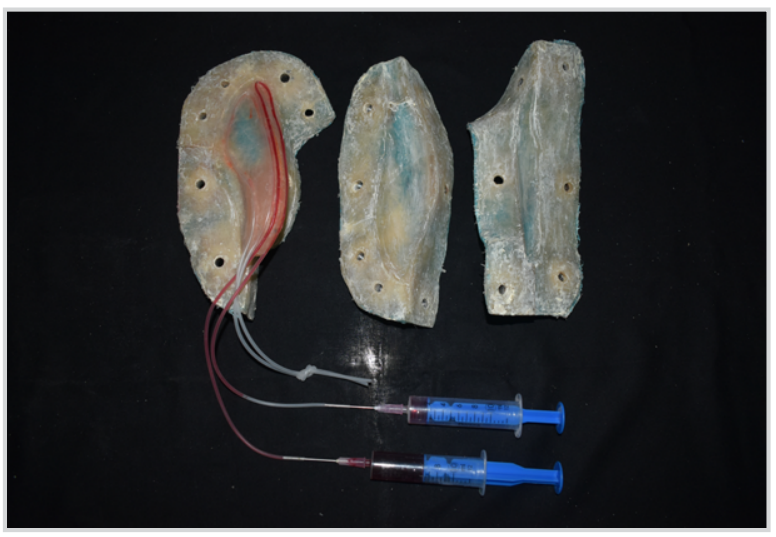

Figure 2. Polyester ear mold. Strong and durable mold for producing numerous replicas of the model. 


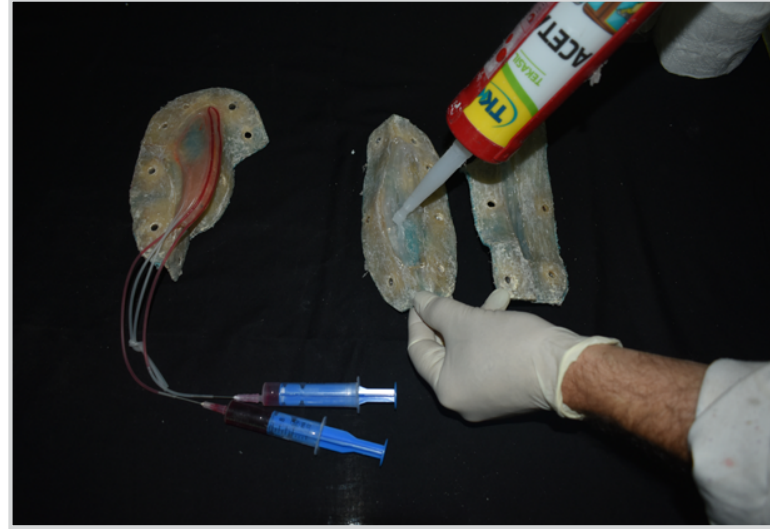

Figure 3 Applying transparent silicone in the mold. Tubes are filled with artificial color and fixated according to anatomical position of marginal ear vein and central ear artery.

silicone tubes were fixed according to lines. After 5-6 hours, silicone would tighten the tubes and they would remain in its position. Two types of silicone tubes (Dejan Plast, Serbia) were purchased:3x2 $\mathrm{mm}$ tube fixed in the right ear and $2 \times 1 \mathrm{~mm}$ tube fixed in the left ear. In the meantime, a thin layer of silicone was applied on the other part of the mold (dorsal side of the ear), and it was drying for few hours. When these two surfaces dried, the silicone was applied on the third connecting part of the mold, and it was sealed by screws (Figure 3). With pressure, the excess of silicone was expelled out of the mold along the junctures (Figure 4).

After 12 hours, the central part merged with the medial and dorsal side, and as a result, we had a beautiful unique form of the rabbit ear. At the end, the ear mold is placed on a flat surface and fixed with needles to acquire its natural position. The important feature of this model is that it is not for single use only. During the practical exercise of the students, a needle penetration hole that appears on tubes is easily fixed with a drop of quick gelatinous

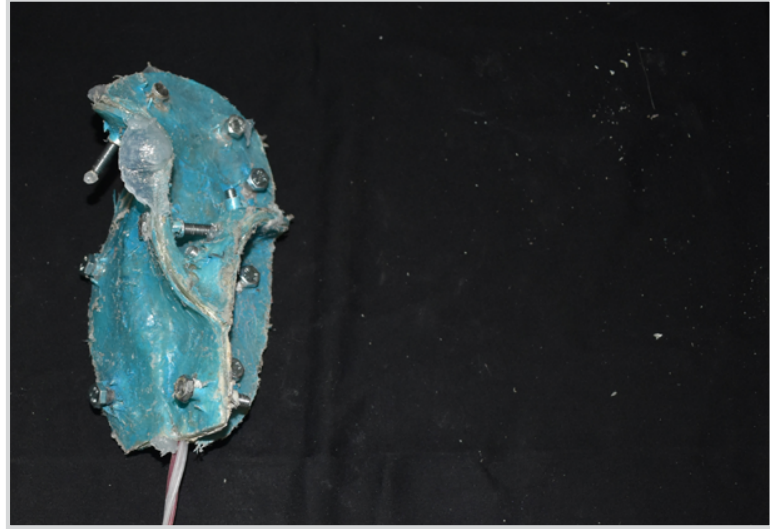

Figure 4 Filled mold connected with screws. The excess of silicone coming out assures the model is compacted.

adhesive compressed with a small piece of cotton wool. Later on, vasopuncturing procedure can be continued further. As blood replacement, we used basic artificial color. Care must be applied since only water-soluble dyes should be used, otherwise silicone tubes could clog.

\section{The rabbit model 'Zlatan'}

On the rabbit cadaver we took a silicone impression and filled it by plaster. After drying, we had a rough form of the rabbit body where some details had to be crafted. Then, vertical cartoon pieces were fixed on the plaster model dividing it to the four parts. Polyester resin plus the catalyst and hardener mixture was applied with fiberglass to make a mold (Figure 5). When it dried, inner surfaces were coated several times by car wax and again a thin layer of polyester resin with fiberglass was applied. Metal bar basis was made previously and placed inside the mold. It was filled with standard foam (Tekapur, TKK, Slovenia) with wet fibers connected with screws and allowed to dry 


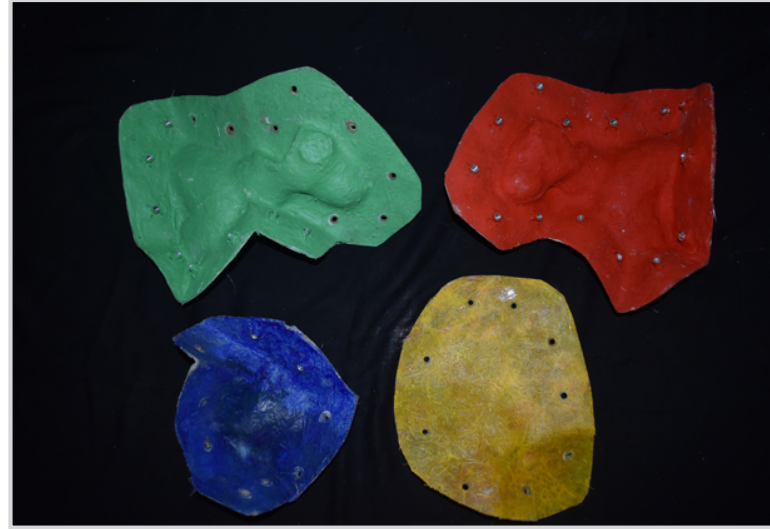

Figure 5 Colored polyester 'Zlatan' mold. Release medium should always be applied before filling the polyester molds.

for 12 hours. To make it all work, mobile parts on the head had to be made separately, and then the rabbit ear is placed and fixed by screws. The axle of the model is simply attached to a truss, and can be turned for $180^{\circ}$ to practise on both ears. That would be the finished light weight, handy and practical rabbit model (Figure 7).

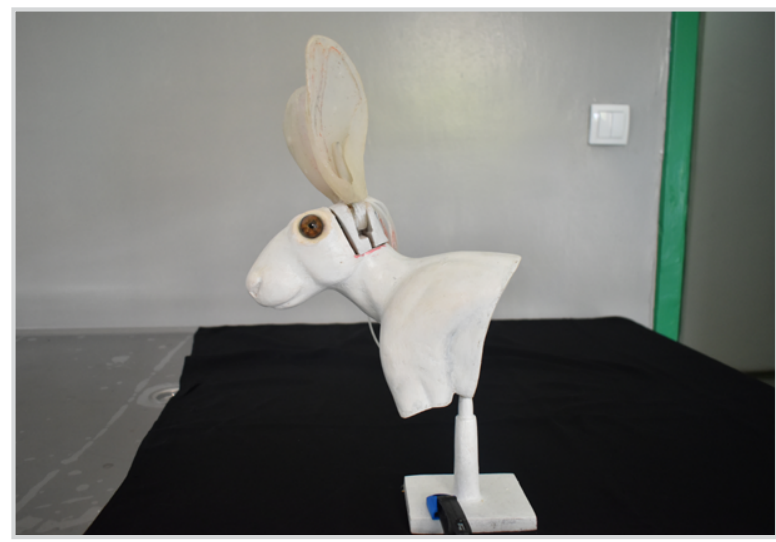

Figure 7 The final form of 'Zlatan', the rabbit model. It is attached to the table by parallel clamp and ready for manipulation.

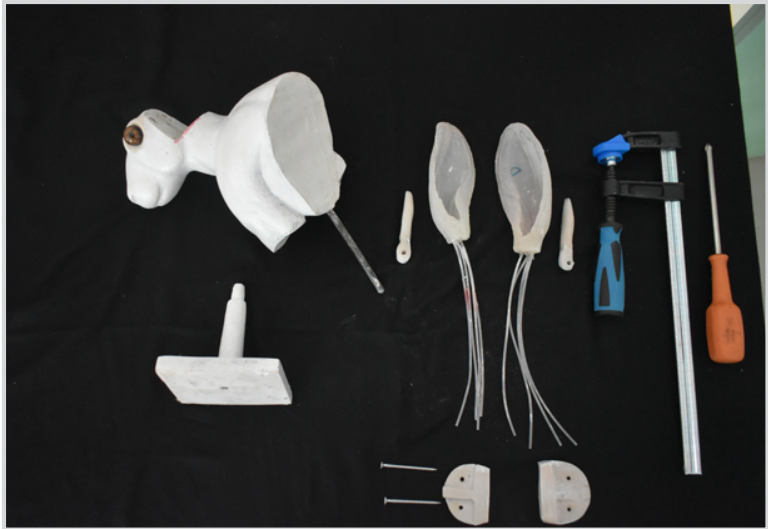

Figure 6 Materials for 'Zlatan', the rabbit model. An excellent method of modeling was developed using cheaper products.

\section{DISCUSSION AND CONCLUSION}

After using and experimenting with various materials, polyester molds gave the best results in making this kind of the silicone model. Although plaster molds gave almost similar results, they lacked stability and durability. European brown hare has naturally bigger ears compared to those

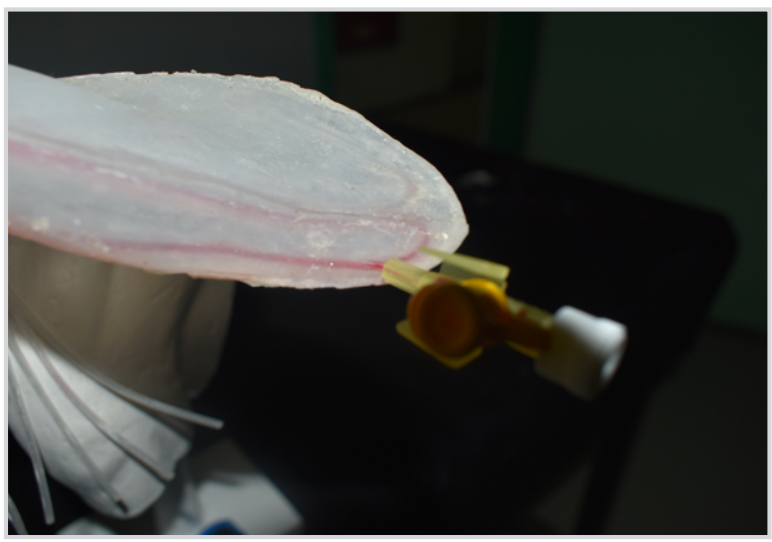

Figure 824 G IV cannula inserted. The silicone thickness simulates realistic ear puncture. 
of laboratory rabbits, so students will definitely find this model easier to practice on. It is almost identical artificial replica of the original ear. It is soft, flexible, durable and reusable. The ear is neither too thin nor too thick, and IV cannula is inserted successfully (Figure 8). Another positive thing is that the right ear has a little wider tubes for students beginners until they get the feeling. The polyester mold can produce any number of models and is long lasting. The 'Zlatan' model is realistic, easy to manipulate with and acceptable both aesthetically and scientifically.

Physical models have great advantages over the textbooks and 3D computer models (Lindgren et al., 2010; Preece et al., 2013). They allow students to move away from discomfort while learning and acquire knowledge faster. We have developed an effective technique for modeling the rabbit ear which can be reused several times and multiplied a number of times from a single mold. The described silicone technique is both simple and inexpensive, requires no complex equipment and produces a detailed positive model, flexible and robust enough to withstand repeated handing and inspection (Grossman et al., 2011).

\section{ACKNOWLEDGEMENT}

The authors thank Jovana Šupić, DVM, assistant from Veterinary Faculty, University of Sarajevo, Bosnia and Herzegovina for acquisition of photographs for this project.

\section{CONFLICT OF INTEREST}

The authors declare no conflict of interest.

\section{REFERENCES}

Arnautović I, Henry RW, Pobrić H, Avdić R, Ćutahija V, Tabaković M, et al. 2005. Improved method for dried anatomical specimen preparation. Journal of the International Society for Plastination, 20, 13-5.

Avdić R, Arnautović I, Pobrić H, Tandir F, Ćutahija V. 2006. Plastination as a method of conservation of anatomical specimens, in: Second B\&H symposium Morphology in science and practice with international participation. p. 27.

Avdić R, Hadžiomerović N, Katica A, Mlaćo N, Bejdić P, Tandir F, Ćutahija V. 2014. Preservation techniques in veterinary anatomy, in: International VETistanbul group congress. p. 7.

Cod AM, Choudhury B. 2011. Virtual reality anatomy: Is it comparable with traditional methods in the teaching of human forearm musculoskeletal anatomy? Anat Sci Educ, 4, 119-25.

Estevez ME, Lindgren KA, Bergethon PR. 2010. Anovel threedimensional tool for teaching human neuroanatomy. Anat Sci Educ, 3(6), 309-17. https://doi.org/10.1002/ase.186.
Grossman CJ, Hamilton R, Close-Jacob LA, De Wit M, Werwa J. 2011. Silicone Modeling of the Interior Spaces of Hollow Organs: Use in Dog and Manatee Respiratory Tract and in a Beef Heart. OnLine Journal of Biological Sciences, 11(1), 7-12. https://doi.org/10.3844/ojbsci.2011.7.12.

Preece D, Williams SB, Lam R, Weller R. 2013. "Let's Get Physical": Advantages of a physical model over 3D computer models and textbooks in learning imaging anatomy. Anat Sci Educ, 6(4), 216-24. https://doi.org/10.1002/ase.1345.

Ravik M, Havnes A, Bjørk IT. 2017. Conditions affecting the performance of peripheral vein cannulation during hospital placement: a case study. Nursing research and practice. Article ID 9748492. https://doi.org/10.1155/2017/9748492.

Seo JH, Malone E, Beams B, Pine M. 2021. Toward Constructivist Approach Using Virtual Reality in Anatomy Education. In Uhl JF, Jorge J, Lopes DS, Campos PF, (Eds), Digital Anatomy (pp. 343-66). Berlin/Heidelberg, Germany: Springer. 


\section{ALTERNATIVNE METODE VAZOPUNKCIJE U VETERINARSKOJ MEDICINI: VJEŠTAČKO ZEČJE UHO}

\section{SAŽETAK}

Studenti veterine često uče izvoditi osnovne procedure na živim životinjama koje su pribavljene iz laboratorija ili skloništa za životinje. U eri suvremenih tehnologija prisutni su stalni napori da se žive životinje zamijene alternativnim vještačkim modelima. Vježbanje na različitim anatomskim modelima doprinosi boljoj kvaliteti budućeg pristupa studenata životinjama u praksi. U svrhu našeg istraživanja su izvedeni brojni eksperimenti na različitim materijalima dok nije pronađeno rješenje $u$ obliku jeftinijeg, ali učinkovitog metoda alternativnog učenja. Stvorili smo vještačko zečje uho kako bismo vježbali i savladali tehniku vazopunkcije iz marginalne ušne vene i centralne ušne arterije. Napravljeno od silikonskih materijala, ono daje elastičnost i mekoću koje su najsličnije ušnoj školjki, dok su krvne žile zamijenjene sa unutarnjim cjevčicama ispunjenim vještačkom bojom. Model predstavlja anatomski tačne karakteristike uha evropskog smeđeg zeca (Lepus europaeus), a ima dvostruku ulogu, pri čemu je naglasak stavljen na ispravno i, naravno, humano učenje.

Ključne riječi: anatomski modeli, zečje uho, silikonski modeli, vazopunkcija 